\title{
From Hope to Disillusion
}

\section{The Paradox of Komnas HAM, the Indonesian National Human Rights \\ Commission*}

\author{
Ken Setiawan
}

McKenzie Research Fellow, Asia Institute, The University of Melbourne setiawan.k@unimelb.edu.au

\begin{abstract}
In recent years, the Indonesian National Human Rights Commission (Komnas HAM) has come under increasing scrutiny as a consequence of its internal problems as well as the persistent refusal of other state bodies to cooperate with the organization. The current situation is remarkable when considering the improvements made to the commission's legal status and mandate. This article will identify internal and external factors that influence the organization's functioning and pay particular attention to how politicization has adversely impacted on Komnas HAM. It will be argued that the politicization of the commission is a direct consequence of the changes made to the organization as part of human rights reforms. That these reforms have failed to strengthen Komnas HAM is a reflection of the low quality of Indonesia's democracy and the challenges the country faces in the implementation of human rights.
\end{abstract}

* This article is based upon doctoral research conducted at the Van Vollenhoven Institute (Vvi), Leiden University, the Netherlands, with funding from the Netherlands Organisation for Scientific Research (Nwo). Most of the data used for this article were collected during several fieldwork periods in Indonesia, during which I was given generous access to the Indonesian Human Rights Commission (Komnas HAM). I would like to thank past and present commissioners and staff members, as well as informants outside the commission, for their willingness to be interviewed. I am also grateful for the comments of two anonymous reviewers. Most of all, I benefited from constructive discussions with, and comments from, Jan Michiel Otto, Herlambang Wiratraman, and in particular Adriaan Bedner on earlier drafts. Any shortcomings that the reader may detect are my own.

(C) KEN SETIAWAN, 2016 | DOI: 10.1163/22134379-17201002

This is an open access article distributed under the terms of the Creative Commons Attribution-Noncommercial 3.o Unported (CC-BY-NC 3.0) License. 


\section{Keywords}

Indonesia - human rights - Komnas HAM - national human rights commissions national human rights institutions

\section{Introduction}

In February 2013 the Koalisi Masyarakat Sipil untuk HAM dan Komnas HAM (Civil Society Coalition for Human Rights and Komnas HAM) issued a press statement claiming that the Komisi Nasional Hak Asasi Manusia (Indonesian National Human Rights Commission; hereafter Komnas HAM) was in a perilous situation (di ujung tanduk). This followed the commission's decision to change its rules of procedure in order to allow one-year terms for the position of chairperson. ${ }^{1}$ A few months later, human rights NGo KontraS (Komisi Untuk Orang Hilang dan Korban Tindak Kekerasan, Commission for the Disappeared and Victims of Violence) reported the commission to the National Ombudsman for its poor performance. ${ }^{2}$

The strong criticism of Komnas HAM contrasts with the positive perception of the commission during the last years of the Soeharto regime (Setiawan 2013:44). This is somewhat of a paradox considering the dramatic change in socio-political contexts that Komnas HAM has witnessed: from operating within an authoritarian state, it now functions within a democracy (Aspinall 2010:20). ${ }^{3}$ Inevitably, this raises the question of why Komnas HAM yields less public legitimacy 4 in a democratic context than it did when operating under a repressive regime.

This article seeks to answer this question by discussing a number of key events in the commission's history, which has been approached from the perspective of the organization itself by using data obtained primarily through interviews with (former) commissioners and staff members. Particular attention is paid to the interplay between context, which refers to both the political

1 This change will be discussed in more detail below.

2 'National scene: Kontras report Komnas HAM to ombudsman', The Jakarta Post, 9-4-2013, http://www.thejakartapost.com/news/2013/o4/og/national-scene-kontras-report-komnas -ham-ombudsman.html (last accessed 29-10-2015).

3 Aspinall (2010:32) has argued that Indonesia's democracy can be seen as both a success story, as well as an example of a low-quality democracy.

4 Public legitimacy is defined as the extent to which a national human rights institution has become a trusted part of the human rights system in a country (ICHRP 2004:5). 
(state) and societal spheres (cf. Faundez 1997:5), and internal dynamics, and how they have both influenced the commission's functioning or performance. Performance is defined, based on the organizational theory of government agencies, as the process by which an organization executes its tasks (Setiawan 2013:22). While the tasks of Komnas HAM include education, research, mediation, and mandate, this article focuses primarily on the commission's functioning in its investigations into cases of alleged gross human rights violations. This choice was made because these investigations attract most attention and therefore strongly influence public legitimacy.

Performance is considered a neutral concept and thus has no normative connotation, which allows performance to be poor, excellent, or anything in between (Setiawan 2013:23). Good performance is crucial for Komnas HAM as it is an important step towards effectiveness, which is defined as the extent to which an organization meets its goals. In the case of a National Human Rights Commission this is regarded as the organization's ability to make a substantial contribution to the protection of human rights (Setiawan 2013:23). ${ }^{5}$ Performance and effectiveness are thus considered to be two separate but related concepts. This differentiation is important, as it provides further nuance in the assessment of National Human Rights Institutions (NHRIs), the wider category of human rights organizations that Komnas HAM belongs to.

The purpose of this article is threefold. First, this article will contribute to academic work on an important actor in Indonesia's socio-legal landscape. ${ }^{6}$ Second, by considering Komnas HAM in its broader context, this article will build on existing work on the nature of Indonesia's democracy and humanrights reform. Third, the article will add to existing literature on NHRIs.

NHRIs are bodies established by governments, whose functions are specifically defined in terms of the promotion and protection of human rights (Centre for Human Rights 1995:6, para. 39). As stated in the 1993 Principles Relating to the Status of National Institutions (commonly referred to as the Paris Principles) NHR Is are advisory bodies: their recommendations 'will never be binding: [...] acceptance by any party must be voluntary and cannot be forced' (Centre for Human Rights 1995:33, para. 272).

5 Effectiveness has a temporal aspect, as it may take time until the programs of an organization trigger the desired change in a society or community (Setiawan 2013:23-4).

6 In-depth discussion on Komnas HAM remains limited to Pratikno et al. 2002; Lay et al. 2002; and Setiawan 2013. Important observations on Komnas HAM and its counterpart in Myanmar in the context of legal transplants were made by Crouch 2013. Discussions of Komnas HAM have also been part of the broader debate on human rights in Indonesia; see for instance Eldridge 2002; Kansil 2003; Herbert 2008; and Hadiprayitno 2010. 
It is believed that 'strong and effective national institutions can contribute substantially to the realisation of human rights and fundamental freedoms' (Centre for Human Rights 1995:1), by embedding international norms in domestic structures (Lindsnaes and Lindholt 2001:44; Mertus 2009:3; Cardenas 2014:2). NHRIs are well placed for this task because of their mandate, which includes investigation, research, and education, and their position: NHRIs are part of the state structure, but do not belong to its traditional branches, potentially enabling them to build bridges between state and society (Kjaerum 2001: np; IC H RP 2004:63, 97; Smith 2006:904; Mertus 2009:3).

Inevitably, the question arises whether NHRIs such as Komnas HAM have been able to fulfil these promises. Academic evaluations of NHRIs have predominantly focused on formal arrangements, including legal status, organizational structure, and mandate, as well as on their impact on the human rights situation. ${ }^{7}$ Nevertheless, little research has considered NH RIs from within. This article argues that by looking at the actual operations of NHRIS and the influence of context on these processes, it is possible to better understand the potential as well as the limitations of these organizations.

This article starts by discussing the establishment of Komnas HAM in 1993 and its performance during the late New Order, explaining which factors contributed to the strong public legitimacy the commission enjoyed by 1998. It will then address the changes made to the organization after the resignation of Soeharto, which strengthened Komnas HAM's legal status and gave the commission a strategic position in addressing cases of gross human rights violations. However, these changes did not translate into a better performance of Komnas HAM, let alone effectiveness, as the commission became more vulnerable to indirect external interference. This has been particularly noticeable in the course of the commission's investigations into gross human rights violations. The public legitimacy of Komnas HAM has also been negatively affected by its problematic relationship with the Kejaksaan Agung (Attorney General's Department; AGD) and the armed forces. Internal disputes, including the 2013 decision to rotate the position of the chairperson annually, have also done the Commission's image little good.

7 An extensive discussion of theoretical approaches on evaluating NHRIs is beyond the scope of this article, but in general three evaluation approaches can be distinguished: (1) the structural approach, which uses the 1993 Paris Principles as a benchmark; (2) the mandatebased approach, which assesses NHRIs on their ability to fulfil their mandate; and (3) the impact-based approach, which measures whether the activities undertaken by the NHRI have changed the human rights situation (Mertus 2012:74-90). 
This article will identify internal and external factors that have influenced the commission's performance and public legitimacy. It will highlight that the inability of Komnas HAM to fulfil expectations can be attributed to the politicization - or the situation where political considerations or priorities influence decisions more than merit-(cf. Peters 2013:17 $)^{8}$ of the commission, which is related to Indonesia's low-quality democracy. The position of human rights in Indonesia's democracy is characterized by the inclusion of human rights norms in law, but resistance to their implementation by the political elite (Aspinall 2005:270-2; Hadiprayitno 2010:374).

\section{Komnas HAM in the Late New Order}

\section{Genesis of Komnas HAM}

In June 1993 the Indonesian government set up the National Human Rights Commission (Komnas HAM) by way of Presidential Decree 50/1993. ${ }^{9}$ The announcement was met with scepticism and suspicion. A number of persons approached to become commissioners, including journalist Gunawan Mohamad and lawyer Adnan Buyung Nasution, refused..$^{10}$ Some of those who accepted the invitation to become a commissioner were asked to reconsider: the students of Airlangga University professor Soetandyo Wignjosoebroto asked him to reassess his decision.11

These reactions to the establishment of Komnas HAM were unsurprising, considering Indonesia's weak human rights record, particularly where it concerned the conduct of the military, and the government's strong support for the Asian Values debate (Pompe 1994:86). In addition, the timing of the establishment - a week after a meeting of foreign donors to Indonesia and a week before the UN World Conference on Human Rights in Vienna-did not do Komnas HAM any favours. Lawyer Todung Mulya Lubis commented that the commission was 'a good idea, but [had] some bad public relations.' ${ }^{2}$

Komnas HAM's mandate was formulated quite broadly, with its main tasks including human rights promotion (through education), the studying of international human rights instruments, and investigations into human rights vio-

\footnotetext{
8 For a detailed discussion on forms of politicization and how these have materialized in the case of Komnas HAM, see below, under the heading 'Politicization and it consequences'.

9 Keputusan Presiden no. 50/1993 tentang Komisi Nasional Hak Asasi Manusia.

10 Interview with former commissioner Asmara Nababan, 28-8-2006.

11 Interview with former commissioner Soetandyo Wignjosoebroto, 19-11-2003.

12 'Mengotak-atik yang Tak Kasat Mata', Forum Keadilan, pp. 10-14, 8-7-1993.
} 
lations..$^{13}$ Nevertheless, there were concerns regarding the Presidential Decree. Abdul Hakim Garuda Nusantara, the chairperson of the NG O Lembaga Bantuan Hukum (Legal Aid Foundation; hereafter LBH), pointed out that a Presidential Decree, as an order of the executive, could be revoked at any time, and made the commission answerable to the president rather than to Parliament, as would have been the case if the organization had been established by law. ${ }^{14}$ Other concerns that were raised included those regarding the commission's membership, for which few requirements had been set, apart from the stipulation that commissioners should be 'well-known national figures'.15 In addition, the commission's funding did not seem to be adequately provided for ${ }^{16}$ It therefore seemed as though the commission was denied the prerequisites to develop into an effective watchdog.

While the circumstances surrounding Komnas HAM's establishment were far from ideal, and the provisions of the Presidential Decree left much to be desired, the creation of the commission itself resonated with Indonesia's human rights policies at the time. In the early 1990s, Indonesia started to increasingly engage with the international human rights regime. This was a political necessity: following the end of the Cold War, pressure on Indonesia was mounting, especially regarding the conduct of the military. The 1991 Santa Cruz massacre in Dili was a turning point for Indonesia, as it could no longer deny it faced serious human rights challenges (Jetschke 1999:16o). It was in this light that Indonesia became a member of the UN Commission on Human Rights (UNCHR), and that the Ministry of Foreign Affairs put forward the idea of establishing a human rights commission. Members of the political elite and of the armed forces, such as the chief of staff of the army, Try Sutrisno, responded positively to the proposal (Pratikno et al. 2002:76-8). From this perspective, the establishment of Komnas HAM resonated with the government's policies of engagement with the international human rights regime in order to deflect criticism.

In addition, domestic developments played an important role, with the Indonesian government facing more criticism from within as a consequence of societal changes. Bourchier and Hadiz (2003) have described Indonesian soci-

13 The tasks of Komnas HAM even surpassed the Paris Principles on NHRIs, which specify that quasi-judicial tasks are optional (Setiawan 2013:38).

14 'Mengotak-atik yang Tak Kasat Mata', Forum Keadilan, pp. 10-14, 8-7-1993.

15 Presidential Decree 50/1993, art. 7.

16 The commission's funding was provided by the State Secretariat, which directly supported the Office of the President. For a more detailed discussion, see Setiawan (2013:39). 
ety in the early 199os as one that had dramatically changed due to economic progress and increased education. People had become more aware of the shortcomings of the government, "knew about human rights and gossiped about the corruption of the elite' (Bourchier and Hadiz 2003:16).

The political elite sought to increase its legitimacy through limited liberalization, including a relaxation of censorship and increased public debate, known as keterbukaan (openness). ${ }^{17}$ The establishment of Komnas HAM thus fitted well into this particular time, especially considering the main themes of the policy: hak asasi manusia (human rights) and demokratisasi (democratization) (Aspinall 2005:43-5). However, keterbukaan was not meant as a transition out of the New Order regime, but as an instrument to channel and control domestic movements. As has been argued by Pratikno et al. (2002:34), this was consistent with the government's policy of state corporatism, in which eventually the organization would be co-opted by the government, unable to shield itself from state intervention. Similarly, Aspinall has suggested that the foundation of Komnas HAM was an attempt to create a government-endorsed alternative to LBH, which had become very popular and was considered an opponent of the New Order regime (Aspinall 2005:115).

The establishment of Komnas HAM was thus a response to increasing pressure on the Indonesian government from both international and domestic arenas. ${ }^{18}$ The commission was a response to the concerns expressed and was a minor concession, one meant to appease the critics. ${ }^{19}$ It was not the government's intention for Komnas HAM to become effective; this was ensured by the commission's weak legal status, unclear mandate, and, above all, the context of an authoritarian state.

17 Keterbukaan was announced in 1989, and is commonly considered to have ended in 1994, when the government banned the periodicals Tempo, Editor and Detik (Aspinall 2005:47).

18 Initially, state officials vehemently refuted the influence of international pressure. Soesilo Soedarman, the coordinating minister for politics, law and security, rejected claims of international interference (Smith 1998:34), but this was later denied by Ali Said, who made no secret of the role international pressure played in the decision of the Indonesian government to establish Komnas HAM (interview with former commissioner Satjipto Rahardjo, 9-5-2008).

19 Moerdiono, minister of the State Secretariat, denied this claim and stated that human rights were part of Indonesia's history and the establishment of a human rights commission was therefore self-explanatory (Smith 1998:33). 


\section{Challenging the Security Forces}

Against all odds, the commission managed to surprise its critics. Komnas HAM quickly gained public support, particularly because of the investigations it opened into human rights abuses involving the security forces.

The first of these cases was the murder of Marsinah, a female labour activist. In 1993 Marsinah disappeared following a strike at the factory where she was employed. A few days later, her mutilated body was found and ten employees of the factory were arrested and tortured to confess to the murder. At the request of the lawyer of the accused, Komnas HAM opened an investigation, despite threats by the minister of justice that he would disband the commission (Pompe 1994:95). The investigation was extraordinary, as the military had never been subjected to criticism from state bodies, let alone an inquiry.

The investigation by Komnas HAM led to the release of the accused and gained the commission widespread praise. The LBH expressed its satisfaction, and observers overseas, such as the Dutch minister of foreign affairs Pieter Kooijmans, stated that the report was 'an important step forward for human rights in Indonesia [...] the report was revelatory of the independence of the National Human Rights Commission' (Pompe 1994:97). Nevertheless, the true perpetrators of the killing - Komnas HAM identified the military unit involved in Marsinah's abduction-were not arrested and the case remains unsolved today.

Other investigations initiated by Komnas HAM included the cases of Liquisa, ${ }^{20}$ Timika, $^{21}$ and the 1996 PDI Affair. ${ }^{22}$ Similar to the Marsinah case, these investigations all concerned transgressions perpetrated by the security forces. In addition, the cases of Liquisa and Timika were politically sensitive,

20 In January 1995, six civilians in East Timor were killed during a military operation. Komnas HАM concluded that there was evidence of torture and unlawful killing (Komnas HAM 1995:41-3).

21 In this investigation, Komnas HAM argued that between October 1994 and June 1995, people in Timika, Fak-Fak, and Desa Hoea had become the victims of indiscriminate killings, torture, unlawful arrest, arbitrary detention, enforced disappearance, excessive surveillance, and the destruction of property. The commission held the armed forces responsible (Komnas HAM 1995:48-50).

Following the 1996 PDI congress, 5 persons were killed and 23 disappeared. More than 140 persons were wounded and another 136 arrested. Komnas HAM concluded that the rights to freedom of assembly and association were violated, as well as the freedom from cruel and inhuman treatment, and the right to life. The commission furthermore argued that the violence was 'a reflection of the political and security policy' (Komnas HAM 1996:317). 
as they were situated in separatist regions (East Timor and Papua respectively), where the government defended human rights abuses as a necessity to preserve national unity and stability. Likewise, the investigation into the PDI Affair was sensitive as it concerned the repression of oppositional politics by the New Order regime. In these cases, Komnas HAM named and shamed those involved, and thus delivered a clear message to both state bodies and society that the behaviour of the state apparatus was not above the law. While in none of these cases the commission could ensure that those responsible for the violations were held to account, the investigations gained Komnas HAM legitimacy, trust, and authority (Pratikno et al. 2002:153).

\section{A Centre of Hope}

The ability of Komnas HAM to conduct and produce high-quality investigations into the cases above meant that the commission performed well, which raises the question what factors contributed to that result. Komnas HAM's good performance was influenced by external factors and, surprisingly enough, the overall supportive attitude of state bodies towards the commission. For instance, Komnas HAM was able to conduct prison visits, even though this was not explicitly provided for in its mandate. Former commissioner Asmara Nababan attributed this to the limited awareness government officials had of Komnas HAM's tasks, as well as the perception that the commission was a 'personal order from Soeharto'. As such, the commission's requests were often honoured. ${ }^{23}$ The opportunities that were given to Komnas HAM were also beneficial for the government, as good performance of its human rights commission could have a positive impact on the New Order's national and international image.

The space that Komnas HAM was given in its early years was perhaps also representative of the increasing divergences within Indonesia's political elite regarding human rights issues. The limited interpretation of human rights propagated internationally by Indonesia was by no means shared by all of its representatives (Aspinall 2005:51-85). Komnas HAM was thus able to take advantage of the cracks that had started to appear in the New Order facade.

Internal factors were crucial in enhancing Komnas HAM's performance. Former commissioners and staff of the commission consistently refer to the role of Ali Said, the first chairperson. Ali Said's appointment to Komnas HAM was not without controversy. ${ }^{24} \mathrm{~A}$ retired army general and high-ranking government

\footnotetext{
23 Interview, 28-8-2006.

24 Human rights activist Poncke Princen argued that Ali Said, in his capacity as chairperson
} 
official, he was described as a 'loyalist' who, as chairperson of the Supreme Court, was of the opinion that the 'judiciary should be kept on a leash [and] ensure from within that government interests would be adequately protected' (Pompe 2005:123-4). Taking this into account, Said's appointment was consistent with the government's desire to keep an eye on Komnas HAM's operations and ensure that it would not undermine government priorities.

However, Ali Said's affiliation with the New Order and personal relationship with Soeharto also meant that he was not afraid of government officials, in which circles he also yielded significant authority as he did with the security forces. ${ }^{25}$ This was evident in a meeting with the military, when a colonel described Komnas HAM as 'an unnationalistic institution influenced by foreign agents'. Soetandyo Wignjosoebroto, who was present at the meeting, stated that 'Ali Said was furious. He smashed his fist on the table and gave him [the colonel] a piece of his mind'. ${ }^{26}$ Similarly, Baharuddin Lopa, who was deputy chairperson, recollected that Ali Said urged him to 'take care of the independence of Komnas HAM, because only by being independent it can take a step towards, and achieve, feelings of justice within society' (Lopa 1997:229). It appears that Ali Said had a vision for Komnas HAM: he wanted the commission to do well, even in its restricted environment. Said's position within the New Order regime also ensured that he could access these organizations and command respect, and therefore assistance, from them. ${ }^{27}$

Former commissioners and staff of Komnas HAM have stated that the leadership of Ali Said, together with Baharuddin Lopa, had a positive influence on the commission. According to Wignjosoebroto, they were able to mitigate inappropriate opinions' (suarayang kurang pas) within the commission. ${ }^{28}$ Komnas HAM also gained support as it communicated openly with the press and the general public, while at the same time adhering to a strict (yet unwritten) rule that internal differences were not to be made public. ${ }^{29}$ Material rewards for this

of the extraordinary court martial following the 1965 events, had violated human rights ('Mengotak-atik yang Tak Kasat Mata', Forum Keadilan, pp. 10-14, 8-7-1993).

25 Interviews with former commissioners Soetandyo Wignjosoebroto, 19-11-2003; Albert Hasibuan, 8-9-20o6; Satjipto Rahardjo, 9-5-2008; and staff member Roichatul Aswidah, 185-2004.

26 Interview, 19-11-2003.

27 Interviews with former commissioners Soetandyo Wignjosoebroto, 19-11-2003; Satjipto Rahardjo, 9-5-2008; and Saafroedin Bahar, 28-8-2006.

28 Interview, 19-11-2003.

29 Interview with former commissioner Soetandyo Wignjosoebroto, 19-11-2003; and staff member Roichatul Aswidah, 18-5-2004. 
behaviour were minimal, as both staff and commissioners only received modest compensation. This meant that in its early years there was a high level of commitment within Komnas HAM.

The internal strength of Komnas HAM was remarkable considering the political context in which it was operating - an authoritarian regime-and the division that existed between its members due to the differing backgrounds of the commissioners. According to former commissioner Soetandyo Wignjosoebroto, Komnas HAM members could be divided into two groups. ${ }^{30}$ The first were the 'nationalists', consisting of former members of the security forces and bureaucracy, who argued against the universal application of human rights norms. The second group, the 'humanists', were formed by academics and NGO representatives and supported universality. ${ }^{31}$ This division was one that, as will be shown later in the article, remained highly relevant for Komnas HAM in the post-Soeharto period.

In 1996 academic and New Order critic Arief Budiman conceded that 'over time, [the commission] developed better than we expected' (Sen 1996:7). This favourable perception of Komnas HAM is remarkable as the commission was not effective: human rights violations remained a systematic part of state behaviour and thus Komnas HAM's activities did not lead to an improvement in human rights conditions. However, the authoritarian context meant that Komnas HAM's willingness to open investigations into violations of human rights were valued and considered an achievement.

Komnas HAM's performance can be attributed to internal factors, such as strong leadership and a general agreement in the commission on its tasks. In addition, external factors played a positive role, with overall support from other state bodies for Komnas HAM's work. The legitimacy Komnas HAM enjoyed in this period is most likely also influenced by the limited number of human rights organizations in Indonesia at the time. Therefore, an organization speaking out against human rights violations, particularly at the state level, could count on receiving public support (Setiawan 2013:50).

Komnas HAM's main achievement in its first years was thus that it demanded attention for human rights and, in doing so, legitimized their very notion. According to former staff member Ratih Rosmayuani, in this period 'Komnas

30 Interview, 19-11-2003. The existence of two groups within Komnas HAM was confirmed by former commissioner Saafroedin Bahar, who labelled the groups 'pro-state' and 'anti-state' (interview, 28-8-2006).

31 The issue of universality aligns with the Asian Values debate, which was prominent at the time. 
HAM was a centre of hope. It was a place where, at last, people could talk freely' ${ }^{32}$ This creation of a space for human rights should not be underestimated, especially in a repressive context where these norms were often construed as alien and dangerous for the nation, and were violated on a structural basis. By speaking out against state-sponsored violence, Komnas HAM strengthened the domestic human rights movement. That Komnas HAM was not able to change human rights practices or policies underlined that the Soeharto regime was repressive and resistant to human rights norms. This suggested that the commission needed a more favourable environment to reach its full potential, which emerged in 1998.

\section{Reforming Komnas HAM}

\section{Enhancing Legal Status and Mandate}

The fall of the New Order in May 1998 heralded a period of reform. At the societal level, there was a rapid growth of civil society organizations, including NGOs concerned with human rights, and the development of vibrant, independent, and more diverse media. ${ }^{33}$ At the state level, several state institutions charged with human rights were established, such as Komnas Perempuan ${ }^{34}$ (Komisi Nasional Anti Kekerasan Terhadap Perempuan, the National Commission on Violence Against Women) in 1998; and the following year saw the creation of the Direktorat Jenderal Hak Asasi Manusia (Directorate General on Human Rights) within the Ministry of Justice and Human Rights. The government also issued its first National Action Plan on Human Rights (Rencana Aksi Nasional Hak Asasi Manusia, or RANHAM).

Human rights were also included in national legislation, through the ratification of all core international human rights treaties, ${ }^{35}$ as well as amendments to

32 Interview, 11-5-2004.

33 However, despite these developments Indonesia struggles with the implementation of human rights; see, for instance, Hadiprayitno 2010 and Azhar 2014. For a detailed study on press freedom in Indonesia, see Wiratraman 2014.

34 The creation of Komnas Perempuan in 1998 was a direct response to the sexual abuse suffered by ethnic Chinese women during the May riots, although the Indonesian women's movement had been lobbying for such a commission for a few years.

35 Notably, these include the ratification of the International Covenant on Civil and Political Rights (ICCPR) and the International Covenant on Economic, Social and Cultural Rights (ICESCR) in 2006. In 1998 Indonesia ratified the Convention Against Torture and Other Cruel, Inhuman or Degrading Treatment or Punishment (СAT), followed by the Conven- 
existing laws. Among these changes was the Second Amendment to the Constitution (2002), which saw the introduction of a specific chapter on human rights (Chapter XA), modelled on the Universal Declaration of Human Rights (UDHR) (Indrayana 2007:233; Lindsey 2008:29; Herbert 2008:457).

Indonesia's ratification of international treaties, amendments to the Constitution and the establishment of institutions related to human rights, meant that Indonesia firmly entrenched human rights norms ${ }^{36}$ in its legal system. From then on Komnas HAM could thus rely on a much more comprehensive legal framework, which should be an advantage for the organization. Moreover, between 1999 and 2001 two laws were passed that directly affected Komnas HAM's legal status, mandate, and powers. ${ }^{37}$

First, the 1999 Human Rights Law ${ }^{38}$ (henceforth HRL) includes a specific chapter on Komnas Ham (Chapter VII), which replaced the 1993 Presidential Decree. This brought Komnas HAM's legal status into conformity with international standards on NHRIs. ${ }^{39}$ The HRL also expanded Komnas HAM's mandate, by adding mediation to its tasks of education, research, and investigation, and accorded the commission the power of summons. ${ }^{40}$ Other important changes

tion on the Elimination of Racial Discrimination in 1999. In 2000 Indonesia signed the Optional Protocol to the Convention on the Elimination of All Forms of Discrimination Against Women (CEDAW, ratified in 1984); in 2001, both Optional Protocols to the Convention on the Rights of the Child (CRC, ratified in 1990); in 2004, the Convention on the Protection of Rights of All Migrant Workers and Members of their Families (ICRMW); and in 2007, the Convention on the Rights of Persons with Disabilities (ICRPD).

36 At the same time, Indonesia also included human responsibility in its laws on human rights, for instance in art. 28J of the Constitution and art. 2 of the 1999 Human Rights Law. The inclusion of human responsibility can be seen as an indicator of the importance of relativism. Similarly, the 1998-2003 National Action Plan on Human Rights stated that the promotion and protection of human rights should be inspired by Indonesian values and traditions, including 'balance and harmony [...] between the rights of the individual and his/her responsibility to the community and the nation'. For an extensive discussion, see Hadiprayitno 2010.

37 In addition to the laws discussed in this article, art. 8(1) of the Law 40/2008 on the Elimination of Racial and Ethnic Discrimination (Undang-Undang no. 40/2008 tentang Penghapusan Diskriminasi Ras dan Etnis) states that the monitoring of all efforts towards eliminating racial and ethnic discrimination is carried out by Komnas HAM.

38 Law no. 39/1999 (Undang-Undang tentang Hak Asasi Manusia).

39 The Paris Principles state that the mandate of NHRIs should be laid down in a constitutional or legislative text. The assumption is that this will make them less likely to be overturned (Cardenas 2014:9).

$40 \quad$ Art. 83(3)(a), art. 94, art. 95 . 
were the explicit provision for the establishment of regional offices, ${ }^{41}$ in line with the government's policy of the decentralization of the administration, and the inclusion of the commission's funding in the National Budget. ${ }^{42}$

Changes were also brought to the selection of members, with the law explicitly calling for commissioners with a track record in the promotion and protection of human rights. The HRL also explicitly calls for plural representation, which means that members should include NGO representatives and academics. ${ }^{43}$ The selection procedure, hitherto an internal process, has been opened up to public participation, as part of which the final election is conducted by a parliamentary commission. ${ }^{44}$ To alleviate the workload of commissioners, the maximum number of members has been increased to 35 , and the position of general secretary is no longer held by a commissioner, but by a civil servant. ${ }^{45}$

On paper, these changes were improvements for Komnas HAM. The inclusion of Komnas HAM in the HRL strengthened its legal status. The power of summons is an important tool in conducting investigations, and the new appointment procedure brought an end to the non-transparent election of members. These improvements were welcomed internationally, and Komnas HAM subsequently obtained an ' $\mathrm{A}$ ' accreditation from the International Coordinating Commission for NHRIs. ${ }^{46}$

Second, the 2000 Human Rights Courts Law (HRCL) ${ }^{47}$ has given Komnas HAM the sole authority to conduct preliminary investigations into cases where gross human rights violations are suspected. If in such a preliminary investigation the commission concludes gross violations have taken place, Komnas HAM forwards its findings to the Attorney General's Department (AGD), which then may start a formal investigation. ${ }^{48}$ If the AGD comes to similar conclusions, prosecution through either the permanent or ad hoc human rights courts

\footnotetext{
41 Art. 76(4).

42 Art. 98.

43 Art. 84(a)-(d).

44 Art. 83(1).

45 Art. 83(1).

46 See http://www.ohchr.org/Documents/Countries/NHRI/Chart_Status_NIs.pdf (last accessed March 2015). Compliance with the Paris Principles is important for NHRIs, as an 'A' status means they can participate in meetings of the UN Human Rights Council. Likewise, full membership of the Asia Pacific Forum (APF) of NHRIs is reserved for organizations that have received the highest accreditation.

47 Law 26/200o (Undang-Undang Pengadilan Hak Asasi Manusia).

48 Art. 20(1), art. 21(1).
} 
should follow. The establishment of an ad hoc court for cases that occurred before the enactment of the law (that is, the year 2000) needs to be approved by Parliament. ${ }^{49}$ The task to conduct preliminary investigations has placed Komnas HAM in a strategic position to address human rights violations. This is a role of great political and social relevance in a country that has witnessed many brutal human rights abuses, most of which remain unresolved. The powers bestowed upon Komnas HAM, combined with the political and societal reforms that Indonesia witnessed, meant that the commission's future seemed bright.

\section{Komnas HAM under Pressure}

The changes made to Komnas HAM's legal status and mandate gave the commission the opportunity to play an important role in addressing human rights violations, which meant that the commission's activities carried more weight than before. However, not everyone-including within Komnas HAM-supported this development, which became apparent in a number of its investigations.

The first of these investigations concerned the violations committed by the security forces and pro-Indonesian militia in Timor Leste following the 1999 referendum. ${ }^{50}$ Komnas HAM's report, which concluded that systematic human rights violations had taken place, caused significant commotion among the political elite and the security forces (Lay et al. 2002:122). As a result of the inquiry, Wiranto, the former chief of staff of the armed forces and at the time coordinating minister of politics and security, was forced to resign. ${ }^{51}$

While the report was welcomed by civil society, it was controversial within the commission itself. Commissioners with a background in the armed forces and administration did not agree with the public naming and shaming of

49 Art. 43(2). The decision by Parliament is formalized by way of a Presidential Decree.

5o Violations committed in Timor Leste before 1999 (that is, the cases of Santa Cruz in 1991 and Liquisa in 1995) were thus excluded from this investigation. As noted above, Liquisa was investigated earlier by Komnas HAM.

51 The Attorney General's Department launched a subsequent investigation, which led to the establishment of an ad hoc court. Twenty people were tried in this court, but most were acquitted. Five persons were sentenced to between three to ten years in prison, but were then acquitted at various stages of their appeal. See http://www.kontras.org/data/Matrix \%2oPutusan\%2oPengadilan\%2oHAM\%2odi\%2oIndonesia.htm (last accessed April 2015). 
those involved, and wanted these to be only made known to the AGD and the president (Lay et al. 2002:123).

In early 2000, Komnas HAM decided that in the case of Maluku, ${ }^{52}$ in which there were clear indications of military involvement, it would not open a formal investigation but would mediate between the parties involved in the conflict. This angered many observers, who argued that the commission ignored crimes committed in Maluku. The commission's approach to this case also contradicted its policy of only mediating in labour and land disputes. ${ }^{53}$ Similarly, in 200o, during the commission's investigation into the Tanjung Priok case, ${ }^{54}$ a group of commissioners strongly opposed the inclusion of NGO representatives in the investigation team, as had been the practice in previous cases. According to former commissioner Asmara Nababan, this had a negative influence on the quality of the investigation, as it was more difficult to secure access to families of the victims. ${ }^{55}$ Indeed, the report on Tanjung Priok is generally considered to be unsatisfactory, with the commission failing to address the role played by the then commander of the armed forces, General Moerdani, as well as Regional Commander Try Sutrisno (Lay et al. 2002:184-6).

The differences of opinion in the immediate post-Soeharto period revolved around two groups within Komnas HAM: members with a background in the armed forces and administration on the one hand (the 'nationalists'), and those from NGOs and academia on the other (the 'humanists'). As has been discussed earlier, this division itself was not new; rather, what changed was that the divergences became more profound - and more visible to outside observers.

Whereas previously the division within Komnas HAM focused on the notion of universality of rights, in the immediate post-Soeharto period it revolved around what role the commission should play in a democratizing Indonesia. ${ }^{56}$

$5^{2}$ In early 1999 communal conflicts erupted in the eastern Indonesian province Maluku, involving Islamic and Christian groups. The security forces were widely regarded to have been the instigators of this violence, allegedly siding with militant Muslim groups. By 2000 an estimated 3,000 people were killed and more than 500,000 were displaced. Interview with staff member Ratih Rosmayuani, 11-5-2004.

54 In this 1984 incident, according to official sources, the security forces killed fifty protestors although more realistic estimates put the number closer to 500 (Vickers 2005:178). The Attorney General's Department confirmed Komnas HAM's findings and an ad hoc court was established in 2003. Out of fifteen defendants, one was sentenced to ten years imprisonment, with others receiving lesser sentences. All were released between 2005 and 2006. Interview, 28-8-2006.

56 The division of Komnas HAM was also noticeable in discussions on the new mandate. For a detailed discussion, see Setiawan (2013:51-2). 
While some commissioners wanted Komnas HAM to take full advantage of its new possibilities and changed environment, others preferred the commission to take a less confrontational position.

The increasing contestation of the nature and processes of Komnas HAM's investigations were directly related to the broadening of its mandate. Those changes strengthened the position of the commission and increased its chances of becoming effective. This was particularly evident in the commission's investigation on Timor Leste, where Komnas HAM showed that it was a force to be reckoned with. That message was not lost on Komnas HAM commissioners, as well as on external stakeholders.

\section{A Weakening Human Rights Commission}

\section{Politicization and Its Consequences}

The changes made to Komnas HAM were very profound, directly impacting on legal status, mandate, and the commission's positioning in the wider effort to implement human rights. The effect of these changes on Komnas HAM in the years that followed can, firstly, be seen in its internal dynamics.

The 1999 HRL changed the manner in which commissioners are appointed to Komnas HAM. ${ }^{57}$ While previously incumbent members elected new commissioners, the HRL determined that a special selection committee, usually consisting of NGO representatives, academics, and retired judges, is responsible for making an initial selection of candidates.

Once this selection is made, a shortlist is forwarded to a parliamentary commission, which conducts the final assessment. This so-called fit-and-proper test consists of a presentation by the candidates followed by a question-andanswer session. Subsequently, the parliamentary commission elects new members through a vote.

The new procedure was first implemented in 2001 and proved to be a long process, stretching into 2002. A number of commissioners from the 'nationalist' group criticized the selection committee for being too liberal, illustrating the divergences within Komnas HAM. The group then demanded the establishment of a second selection committee, which excluded members of exter-

57 The election procedure is described in detail in Komnas HAM's rules of procedure (peraturan tata tertib). The election of members by Parliament is recommended internationally, as it is considered a reflection of democratic decision-making (Centre for Human Rights 1995:11, para. 79). 
nal organizations. The second committee was established, although there is no basis for this in the commission's rules of procedure. The second committee, consisting of incumbent members only, added names to the first shortlist, including those of candidates who had previously been deemed unsuitable. When the process moved to the parliamentary stage, several candidates without a clear track record in human rights were favoured over a number of wellrespected human rights activists and lawyers. According to sources internal to Komnas HAM and NGO representatives, the new selection process had become subject to party politics, where candidates' political allegiances were of more importance than their affiliation with human rights. ${ }^{58}$

During the 2007 election process NG Os reported that the nature of questions put forward by the parliamentary committee rarely concerned specific human rights problems or challenges faced by Komnas HAM. Instead, candidates were required to answer questions on religious issues, including personal opinions on polygamy, interreligious marriage, and homosexuality. Questions were also asked about the candidates' religious convictions and their opinions about the Ahmadiyah. ${ }^{59}$ This suggested that the parliamentary commission was not so much interested in normative perspectives on human rights, but rather in how candidates' personal views related to the status quo. ${ }^{60}$

With political considerations given such a prominent place in the election process, Komnas HAм became more vulnerable to external interference. This became noticeable in Komnas HAM's investigations.

In 2005 Komnas HAM started an investigation into the 1997/1998 disappearances of 25 activists $^{61}$ under the 2000 H RCL. During the investigation the commission summoned a number of military officials, including the former army chief of staff Wiranto, who refused to appear. However a number of commissioners, who shared with Wiranto a background in the armed forces and who

$5^{8}$ Interviews with staff member Roichatul Aswidah, 25-9-2006; vice-chairperson Zoemrotin K. Susilo, 13-10-2006; former commissioner M.M. Billah, 26-4-2008; and NGO representatives Agung Putri, 29-8-2006; Ifdhal Kasim, 20-9-2006; and Usman Hamid, 9-102006.

$59 \quad$ NGO report on the selection process (on file with author).

6o Personal communication with Indria Fernida (KontraS), May 2008. One candidate, Ita F. Nadia, suspected that her personal and professional association with survivors of the 1965/1966 killings and its aftermath affected her candidacy negatively (personal correspondence, September 2007).

61 Referred to as kasus orang hilang, the case concerns the enforced disappearance of 25 activists of the PRD (Partai Rakyat Demokrasi). Thirteen of them were released, the fate of the other twelve, including poet Wiji Thukul, remains unknown. 
were not part of the investigation team, met him privately. In this meeting, Wiranto stated that the missing persons had died. Although this information was publicized in the media, ${ }^{62}$ it was not included in the commission's report as commissioners not part of the investigation team had obtained the information. ${ }^{63}$ During the presentation of its findings, the investigation team even stated it had no idea what had happened to the missing persons, as it was unable to establish this during the course of the investigation. The omission of this piece of information-based on the argument that the investigation team was unable to obtain evidence- - was a major flaw of the report. It angered members of the victims' families as well as NGO representatives, who argued that the omission of the information would contribute to impunity.

In another example, commissioner M.M. Billah attempted to establish an investigation under the HRCL for the case of the Ahmadiyah. ${ }^{64}$ In 2005, the Ahmadiyah were declared heretical by the Majelis Ulama Indonesia (Indonesian Council of Ulama, MUI) and increasingly subject to systematic violence and discrimination. Billah started by conducting an investigation under the 1999 HRL, which resulted in a 1,00o-page report, in which his investigation team concluded there was clear evidence of gross human rights violations. Billah's proposal for the case to be pursued further under the HRCL was, however, rejected by a majority of commissioners. A crucial role in blocking the proposal was played by another Komnas HAM commissioner, who at that time simultaneously held the position of MUI vice-chairperson. ${ }^{65}$ Komnas HAM eventually

62 'Komnas нам: Wiranto Mengatakan 14 Orang Itu Sudah Meninggal', Tempo Interaktif, 17-2005, http://nasional.tempo.co/read/news/2005/07/01/05563299/komnas-ham-wiranto -mengatakan-14-orang-itu-sudah-meninggal (accessed 29-10-2015).

63 The commissioners who obtained the information from Wiranto and opposed its inclusion in the report were former military officers or affiliated to the Golkar party, of which Wiranto was a prominent member.

64 In the nineteenth century the Ahmadiyah, an Islamic religious movement, was founded in present-day Pakistan. In Indonesia, the movement emerged in the early twentieth century and at present is estimated to have 500,00o followers. An ongoing source of tension with orthodox Islam is the belief that revelation did not cease with the Prophet Muhammad, but that Mirza Ghulam Ahmad (the founder of the Ahmadiyah) was the spirit of the Prophet. Since its arrival in Indonesia, some mainstream Islamic leaders have stated that the Ahmadiyah and its followers are 'deviant'. The MUI is one of the main opponents of the movement, and in 1980 and 2005 issued fatwa (Islamic legal opinions) against the Ahmadiyah (Crouch 2009).

65 According to commissioner Soelistyowati Soegondo (interview, 11-9-2006) there was an active lobby to block Billah's proposal. 
decided to issue a statement in which it condemned the violence against the Ahmadiyah, but no reference was made to the source of the violence, or the MUI's call on the government to ban the group.

These two cases illustrate how interest groups were able to avoid Komnas HAM's scrutiny by using their (personal or professional) relationships with individuals inside the commission. That external groups that feel threatened by the commission's actions try to exert influence over the proceedings is not surprising, but that Komnas HAM conceded to these pressures has had farreaching effects. In the case of the 1997/1998 disappearances, crucial information was missing from the commission's investigation, where in the case of the Ahmadiyah, Komnas HAM responded inadequately. This illustrates that in such cases the political considerations override the case's merits, which can thus be considered as politicization (cf. Peters 2013:16).

Peters (2013) has distinguished a number of types of politicization, three of which are particularly relevant for Komnas HAM. First, the general conceptualization of politicization, where political criteria substitute merit-based criteria in the selection of members (Peters 2013:16) is reflected in the selection process of Komnas HAM members by Parliament. Second, dual politicization, which refers to the ability of the legislature to exert influence on the individuals within an organization (Peters 2013:19), in the case of Komnas HAM as a direct consequence of the manner in which commissioners are selected. Third, the case of the Ahmadiyah shows how social actors have become able to exercise influence on Komnas HAM, which resonates with Peters's concept of social politicization (Peters 2013:19).

These various forms of politicization had serious consequences for Komnas HAM. While Komnas HAM's selection procedure was meant to allow for more transparency and public participation, in practice the commission became exposed to political bargaining. In turn, this affected Komnas HAM's performance adversely, resulting in a weak and compromising ${ }^{66}$ response to pressing human rights concerns.

\section{Internal Challenges}

The politicization of Komnas HAM has influenced its public legitimacy negatively, as have a number of internal problems. Both attracted widespread crit-

66 This resonates with Hadiprayitno's argument that Indonesia's approach towards human rights has historically been one of compromise, and, as such, significant advancements towards the actual protection and promotion of human rights remains difficult (Hadiprayitno 2010:396). 
icism and discontent from Indonesian $\mathrm{NGOs}^{67}$ who took a keen interest in the 2007 election process. NGOs approached candidates to sign contracts in which they committed themselves to working closely with the NGOs and to prioritizing the victims of human rights violations. Most candidates signed the contract. 68

In September 2007 the third parliamentary committee elected eleven commissioners to Komnas HAM. This outcome was, in several ways, a break with the past. No incumbent members were reappointed and the number of commissioners was dramatically reduced ${ }^{69}$ in a bid to enhance decision-making. ${ }^{70}$ Both in 2007 and 2012, no members of the security forces were elected, ${ }^{71}$ which suggested that the inclusion of commissioners with such a background was considered detrimental to Komnas HAM.

However, the different composition of Komnas HAM's membership did not solve its internal problems, which included a failed restructuring of its organization (2004) and staff going on strike over pay disputes (2006). ${ }^{72}$ More recently, in 2013, the commission changed its Rules of Procedure, allowing the position of chairperson to rotate on a yearly basis. This decision was met with strong criticism from a number of commissioners ${ }^{73}$ and NGO representatives, who stated it was a bad decision that will weaken the implementation of [the commission's] work in handling cases of human rights violations.' ${ }^{74}$ SE PA HAM (Serikat Pengajar HAM Indonesia, the Association of Human Rights Lecturers) added that the

67 Interviews with Agung Putri (ELSAM), 29-8-2006 and staff member Roichatul Aswidah, 25-9-2006; personal communication with former Komnas Perempuan member and candidate member of Komnas HAM, Ita F. Nadia, September 2007.

68 Personal communication with Indria Fernida, representative of the NGO KontraS, May 2008.

69 The amount of commissioners elected appears to be at the discretion of the parliamentary committee. During the 2012 election process, factions indicated how many commissioners they wanted to endorse, with numbers ranging between nine and fifteen. Eventually, the parliamentary committee decided on thirteen members (Kontan, 22-10-2012).

70 'Jumlah Anggota Komnas Ham akan Dikurangi', Media Indonesia, 26-3-2007.

71 No commissioners with a background in the bureaucracy were elected in 2007. In 2012 a number of commissioners had a background in the bureaucracy; they had previously served within the Directorate General for Human Rights.

72 For a detailed description of the internal challenges in the 2002-2007 period, see Setiawan (2013:57-6o).

73 The four commissioners who opposed the change walked out during the deliberations (Kompas, 8-2-2013).

74 'Komnas HAM di Ujung Tanduk', ELSAM, 7-2-2013, http://lama.elsam.or.id/article.php?act $=$ content\&id=2270\&cid=302\&lang $=$ in $\# . V j F 9 C r c r K U k($ accessed 29-10-2015). 
decision would, either directly or indirectly, impact negatively on the commission's work. ${ }^{75}$ The disappointment felt by observers was expressed well by Haris Azhar, the coordinator of leading human rights NGO KontraS, who commented that Komnas HAM had become an 'embarrassment' and that the recent developments came at the expense of 'those who are seeking truth and justice in Indonesia. ${ }^{76}$

A commissioner opposing the change, Roichatul Aswidah, stated that she believed one-year terms would have an impact on the focus of the commission, which would become dependent on the individual preferences of the chairperson..$^{77}$ Commissioners supportive of the change, however, claimed that a rotational position for the chairperson was based on the principle of 'collective collegiality' (kolektif kolegial), which would improve staff-commissioner relationships. ${ }^{78}$

Critics of the change have pointed at the material rewards associated with the position of chairperson, including a larger office as well as a car, as an incentive for commissioners' support for the change. ${ }^{79} \mathrm{NGO}$ representatives have argued that political considerations played a role in Komnas HAM's decision to rotate the position of chairperson on a yearly basis, with the intention of weakening the commission. ${ }^{80}$ It is difficult to determine whether the change to the length of the term of the chairperson was indeed influenced by political considerations. If so, then the group with the most direct political relationship with Komnas HAM (the third parliamentary commission, which had

75 'Pernyataan Sikap Serikat Pengajar Hak Asasi Manusia (SEPAHAM) Indonesia tentang Kisruh Internal Komnas HAM', SEPAHAM, 9-2-2013 (on file with author).

76 'Memalukan Punya Komnas HAM Seperti Ini!', Kompas, 8-2-2013, http://nasional.kompas .com/read/2013/o2/o8/12323693/quotmemalukan.punya.komnas.ham.seperti.iniquot (last accessed 29-10-2015). 'DPR Desak Komnas HAM Akhiri Kisruh Internal', Hukum Online, 11-2-2013, http://www .hukumonline.com/berita/baca/lt5119227e95eeo/dpr-desak-komnas-ham-akhiri-kisruh -internal (last accessed 29-10-2015).

78 'DPR Desak Komnas HAM Akhiri Kisruh Internal', Hukum Online, 11-2-2013, http://www .hukumonline.com/berita/baca/lt5119227e95eeo/dpr-desak-komnas-ham-akhiri-kisruh -internal (last accessed 29-10-2015).

79 'Pengajar нам Kecam Komnas HAM', Hukum Online, 13-2-2013, http://www.hukumonline .com/berita/baca/lt511b27f29cb8c/pengajar-ham-kecam-komnas-ham (last accessed 2910-2015); Crouch 2013:165.

8o 'Komnas HAM di Ujung Tanduk', ELSAM, 7-2-2013, http://lama.elsam.or.id/article.php?act =content\&id=2270\&cid=302\&lang=in\#.VjF9CrcrKUk (last accessed 29-10-2015).; 'Pernyataan Sikap Serikat Pengajar Hak Asasi Manusia (sE PAнAM) Indonesia tentang Kisruh Internal Komnas HAM', SEPAHAM, 9-2-2013 (on file with author). 
elected the commission's members in 2012) made every effort to suggest otherwise. Most members - representing different political factions - opposed the change and were concerned about the negative impact it would have on the commission's work. Taslim Chaniago, a Member of Parliament for PAN (Partai Amanat Nasional, National Mandate Party), accused Komnas HAM members of 'seeking popularity rather than prioritizing the quality of [the commission's] performance'. Another MP, Trimedya Panjaitan (Partai Demokrasi Indonesia Perjuangan, or PDI; Indonesian Democratic Party of Struggle), expressed regret on voting for 'power-hungry commissioners' 81

Whatever the exact dynamics of the commission's decision to reduce the duration of the term of the chairperson, developments like this, combined with the effects of politicization on Komnas HAM's performance, have negatively influenced its public legitimacy. Observers of Komnas HAM have also pointed out that after the amendment to the rules of procedure, the commission has overall been silent in the public debate, particularly during the 2014 presidential elections. In addition, they have argued that the commission's performance and relationship with stakeholders depends on a personal, rather than institutional basis. ${ }^{82}$ In addition to these internal matters, the commission's legitimacy has also been eroded by the direct resistance it faces in conducting its work, as will be illustrated in the next section.

\section{A Defensive Environment}

Although Indonesia is now generally considered a democracy (Aspinall 2010:20), it still faces many challenges in the area of human rights implementation (Hadiprayitno 2010; Azhar 2014). In the case of Komnas HAM, this can be seen in the ways in which two main state bodies, the Attorney General's Department and the armed forces, have positioned themselves towards the commission.

The 2000 HRCL gives Komnas HAM a crucial role in addressing gross violations of human rights. If in a preliminary investigation Komnas HAM comes to the conclusion that gross violations have taken place, the case is forwarded to the AGD, which then can conduct its own investigation. If the AGD comes to a similar conclusion, it can start proceedings in the human rights courts. However, the AGD has on various occasions rejected the commission's findings and therefore refused to follow up on cases of gross human rights violations.

\footnotetext{
81 Hukum Online, 11-2-2013.

82 Personal communication with Airlangga University lecturer Herlambang Wiratraman, March 2015. Earlier, I identified that personal interest and commitment of commissioners play important roles in Komnas HAM's performance (Setiawan 2013:69-112).
} 
In 2012 the AGD returned Komnas HAM's report on its investigations into the $1965 / 1966$ massacres $^{83}$ and the $1982-1985$ Petrus $^{84}$ (penembakan misterius, mysterious shootings) case. In both investigations the commission had concluded gross violations had taken place. However, the AGD rejected the findings and commented that it was 'difficult to investigate cases which have happened that many years ago'. ${ }^{85}$ The AGD's rejection of Komnas HAM reports has been recurrent. In 2006, the AGD refused to follow up Komnas HAM's investigation into the 1997/1998 disappearances of activists until Parliament had approved the establishment of an ad hoc court, ${ }^{86}$ an argument that had no basis in the HRCL. In 2002 the AGD did not follow up on Komnas HAM's investigations into the Trisakti, Semanggi I, and Semanggi II cases, ${ }^{87}$ arguing that the documents submitted by the commission were incomplete. ${ }^{88}$ When the commission sent the requested documents, the Attorney General argued that as the members of the investigation team had not been sworn in ${ }^{89}$ the investigation was not valid, even though this is not a requirement of the HRCL. In 2005 the AGD announced it would never open an investigation into the cases, as they did not concern gross violations of human rights. Similar arguments were used in the AGD's

83 When the military took control of government in 1965 , they instigated a violent campaign against communists and their alleged sympathizers, resulting in 'one of the worst bloodbaths of the twentieth century, [during which] hundreds of thousands of individuals were massacred by the army and army-affiliated militias' (Roosa 2006:4).

84 In the early 1980s, public concerns about crime levels increased due to media reports. Subsequently, members of criminal gangs on Java were killed, and their bodies found by members of the public. Off-duty military personnel were widely held responsible for these murders. According to Vickers (2005:181), the killings were a reminder to both gang members and the general public that the state had the 'ultimate monopoly on violence'.

85 'Korban Peristiwa 1965-66 Kecewa dengan Kejaksaan Agung', Voice of America, 12-11-2012, http://www.voaindonesia.com/content/korban-peristiwa-1965-kecewa-dengan -kejaksaan-agung/1543843.html (last accessed 29-10-2015).

86 'Komnas HAM Minta Dukungan DPR', Koran Tempo, 23-11-2006, http://tempo.co.id/hg/ nasional/2002/11/04/brk,20021104-39,id.html (last accessed 29-10-2015).

87 In the Trisakti case (12 May 1998), four students were killed and 681 others were wounded; in the Semanggi I case (8-14 November 1998), 18 demonstrators were killed and 109 wounded; and in the Semanggi II case (24 September 1999), 11 protesters were killed, while 217 were wounded. For a detailed chronology, see http://www.kontras.org/data/KERTAS _POSISI_TSS_2006.pdf (last accessed 1-6-2015).

88 'Komnas HAм Tunggu Surat Jawaban Kejaksaan Agung', Tempo Interaktif, 4-11-2002.

89 Interview with commissioner Ruswiyati Suryasaputra, 29-8-2006. 
rejection of the May $1998^{90}$ as well as the Wasior and Wamena cases ${ }^{91}$ (Komnas HAM 2006:54-6).

In addition, Komnas HAM has been faced with the persistent refusal of armed forces personnel to respond to the commission's summons. The root of this problem is that the commission's right to summons is provided for in the 1999 HRL but not in the 2000 HRCL. This has led (former) armed forces personnel, most prominently the former chief of staff Wiranto, to argue that they have no legal obligation to comply with Komnas HAM's summons in investigations carried out under the HRCL.

In 2008 the refusal of the armed forces to comply with Komnas HAM's requests received media attention following a statement from Defence Minister Juwono Sudarsono, who claimed that the commission had no authority at all to summon military officials. The armed forces commented that they would 'encourage' active military to comply with the commission's requests, but could not ask the same from retired officers, ${ }^{92}$ even though the HRL does not differentiate between active or retired personnel. ${ }^{93}$ Sudarsono later commented that in the case of retired personnel, a written statement would suffice, ${ }^{94}$ which further legitimized the position of the armed forces.

The position of the armed forces in this matter has made it difficult for Komnas HAM to obtain (incriminating) evidence during investigations, and it is also concerning as since 2007 Komnas HAM has expressed its desire to focus

9o This case concerns the riots that took place between 13 and 15 May 1998 in Jakarta, and the killings, disappearances, and rapes that occurred in that period. The security forces, or the hoodlums supported by them, are generally considered responsible for the violence. President Habibie ordered an initial investigation in May 1998, but the government did not respond to the findings of this team. In 2003, Komnas HAM opened its own investigation and concluded gross human rights violations had taken place (Komnas HАM 2006:54-5).

91 In the Wasior (2001-2002) case, 140 persons were detained and subjected to torture or other forms of ill-treatment, with one person dying in custody and at least seven others executed. Twenty-seven were sentenced to imprisonment in trials considered to have been unfair. In the Wamena (2003) case, at least 30 people were detained and tortured by the military, and at least one person died as a direct result (Setiawan 2013:62).

92 'Komnas нам Tak Berwenang Panggil Paksa', Kompas, 6-3-2008, http://megapolitan .kompas.com/read/2008/03/06/2042510/komnas.ham.tak.berwenang.panggil.paksa. (last accessed 29-10-2015).

93 Art. 89(3) of the HRL states that Komnas HAM may call upon any party either directly involved in, or witness to, a case under its investigation.

94 'Purnawirwan tNi Cukup Jawab Tertulis ke Komnas HAM', Kompas, 17-3-2008, http:// megapolitan.kompas.com/read/2008/03/17/21041142/purnawirawan.tni.cukup.jawab .tertulis.ke.komnas.ham (last accessed 29-10-2015). 
on gross violations of human rights. ${ }^{95}$ The commission responded by saying it would take the matter up with the UN Human Rights Council, ${ }^{96}$ and stressed that it wished to summon the officers 'not for revenge, but in order to comply with Indonesia's laws'. ${ }^{97}$

While the widespread attention given to the dispute showcased one of the most pressing external challenges Komnas HAM faces, it also damaged the commission's already precarious relationship with the armed forces, who were disgruntled with the media coverage. ${ }^{98}$ What perhaps further complicated the matter was that Komnas HAM in this period lacked commissioners with a background in the armed forces who could function as intermediaries, as had been done in the past. ${ }^{99}$

In response to the resistance Komnas HAM has faced from both the AGD and the armed forces, the commission has expressed-since 2002-its wish for the HRL and HRCL to be amended. Amendments should include, amongst others, that the commission should be the sole investigator, and the AGD the prosecutor. The power of summons should be provided for in both laws, and the process through which ad hoc human rights courts are established should be further clarified (Setiawan 2013:62-3). Both the HRL and HRCL were included in the 2015-2019 Program Legislasi Nasional (National Legislation Program or Prolegnas).

95 In September 2007 newly elected chairperson Ifdhal Kasim announced that the commission would focus on cases of gross human rights violations, including crimes committed under the New Order regime (Komnas HAM 2008:12). Kasim stated that it was important for the commission to take on these cases in order to 'regain the trust of society' ('Ifdhal Kasim Pimpin Komnas HAM', Koran Tempo, 6-9-2007). In 2012, Otto Nur Adbullah, who had just been elected chairperson, announced he would also pursue gross violations of human rights, including cases that had not been addressed yet by the AGD ('Otto Nur Abdullah mengemban amanat', BBC Indonesia, 11-1-2013, http://www.bbc.com/ indonesia/laporan_khusus/2013/01/130110_tokoh_desember2012_otto_nur_abdullah (last accessed 29-10-2015)).

96 'Menhan: Silakan Bawa ke Dewan нам Рвв', Kompas, 10-4-20o8, http://megapolitan .kompas.com/read/2008/04/10/20523013/menhan.silakan.bawa.ke.dewan.ham.pbb. (last accessed 29-10-2015).

'Komnas HAM Tetap akan Panggil Purnawirawan TNI POLRI', Kompas, 24-4-2008, http://health.kompas.com/read/2008/04/24/16052021/komnas.ham.tetap.akan.panggil .purnawirawan.tni.polri (last accessed 29-10-2015).

98 Personal communication with Hesti Armiwulan, commissioner and vice-chairperson for external affairs, 7-5-2008.

Interview with commissioner Saafroedin Bahar, 25-8-2006. 
In 2013 Otto Nur Abdullah, the then chairperson of Komnas HAM, commented that the positioning of other state bodies, such as the AGD and the armed forces, has impacted negatively on public perceptions of Komnas HAM. Abdullah attributed this to some extent to a lack of understanding of Komnas HAM's powers, in that it is often assumed that the commission can implement its decisions, ${ }^{100}$ but it is also related to the broader context of human rights reform, or the lack thereof, in Indonesia.

The manner in which the AGD and the armed forces have responded to Komnas HAM illustrates that the commission commands little authority. It has been argued that while Indonesia since 1998 has made much progress in the legal and institutional entrenchment of human rights, actual enforcement of these rights and the protection of individuals leaves much to be desired (Hadiprayitno 2010; Azhar 2014). Azhar has attributed this to an unwilling and unable state, with the foreign pressure on Indonesia also not having the desired effects (Azhar 2014:228, 229). Hadiprayitno has argued that the Indonesian state has approached human rights in a defensive manner, characterized by compromise. ${ }^{101}$ This can be seen in the enactment of laws riddled with loopholes (as the HRCL illustrates, with the absence of the power of summons), as well as the ratification of international instruments as an effective political strategy aimed at deflecting international criticism (Hadiprayitno 2010:379, 397).

The challenges towards human rights reform in Indonesia can be explained by taking into consideration that power relations after 1998 were reorganized, but not transformed (Hadiprayitno 2010:396). Aspinall (2010) has argued that an inherent part of Indonesia's democratization has been the accommodation of so-called spoilers. ${ }^{102}$ Their accommodation has reduced the incentives for spoilers to resist or challenge the system, and as such has secured, overall, a smooth transition. This success, however, has come at a price, with the accommodation of these spoilers affecting governance, with few achievements in deepening democratic reform (Aspinall 2010:32-3).

Two of the spoilers singled out by Aspinall resonate with some of the challenges Komnas HAM faces. First, the inclusion of Islamist political forces has

\footnotetext{
100 'Otto Nur Abdullah mengemban amanat', вBC Indonesia, 11-1-2013, http://www.bbc.com/ indonesia/laporan_khusus/2013/01/130110_tokoh_desember2012_otto_nur_abdullah (last accessed 29-10-2015).

101 Preamble and art. 2.

102 Aspinall identifies three spoilers: the military, secessionist movements, and Islamist political forces, which were all given the opportunity to participate in Indonesia's new democracy (Aspinall 2010:20).
} 
been accompanied by a partial Islamization of politics and society. This process has also received support from secular-nationalist parties and leaders who are keen for the support of pious voters. Discourses favouring more orthodox interpretations of Islam have played a role in the government's failure to protect the Ahmadiyah (Aspinall 2010:31), a position that to some extent found support within Komnas HAM, too. Second, while the military have withdrawn from direct political affairs, the civilian government has been reluctant to end certain military prerogatives. This means that little progress has been made in some areas of military reforms, which has resulted in a culture of impunity (Aspinall 2010:22-3). The special position of the military has made it difficult for organizations such as Komnas HAM to call perpetrators of human rights violations to account, which is evident in the commission's difficulties in summoning military personnel.

It has been argued both that Indonesia's democracy can be regarded as a success and that it is of poor quality (Aspinall 2010:31). This paradox echoes true for Komnas HAM: while on paper it can rely on a strong human rights system, the commission struggles in performing its tasks, and therefore its contribution to the implementation of human rights in Indonesia remains limited. Komnas HAM's experiences underline that the entrenchment of human rights norms in law is not enough; political support is indispensable. Therefore, as long as democratic quality remains low and the political elite maintains its defensive (and at times hostile) approach towards human rights implementation, the role of Komnas HAM will at best be limited.

\section{Conclusion}

This article has discussed the development of Komnas HAM in a socio-political context. It has argued that the commission managed to gain public legitimacy in its early years, despite having to operate in a repressive context, due to its investigations into cases involving human rights violations by the security forces. The good performance of Komnas HAM in this period raised expectations that the commission would be able to make a substantial contribution to the protection of human rights in a more democratic context.

However, Komnas HAM did not benefit from a more favourable external environment and improvements to its legal status and mandate. Instead, Komnas HAM has faced many challenges, including direct, external resistance to its work and internal problems related to poor management as well as the politicization of its members. The latter has worryingly led to a failure of Komnas HAM to respond adequately to serious human rights concerns. Paradoxically, 
the commission's performance has been poorer in a democratic context than in that of an authoritarian state.

This is not to suggest that Komnas HAM was better off in the context of a repressive regime. While Komnas HAM's good performance deserves commendation, the commission's work did not result in improvements in human rights policies or practices in the New Order period. However, from the contrast between Komnas HAM's performance in a repressive context on the one hand and more liberal circumstances on the other, a number of observations can be made.

First, the story of Komnas HAM generates important insights for NHRIS in general, including the potential of these organizations to promote human rights norms in repressive contexts. In addition, the experiences of Komnas HAM illustrate that while elements of legal status and mandate are important, they tell little about actual performance and effectiveness, for which a closer look at an organization's dynamics is necessary. This includes the way in which an NHRI reacts in response to, and as a consequence of, its external environment.

Second, this article has presented external and internal factors that influence Komnas HAM's performance. External factors include the positioning of other organizations towards the commission. While in the New Order period Komnas HAM faced little resistance from external organizations, since 1998 the commission has met with increasing opposition to its work. Internal factors refer particularly to the composition of membership and to how individual commissioners perceive their role. Over time, Komnas HAM has experienced increasing fragmentation. The division within Komnas HAM has been amplified through the politicization of its membership, a direct consequence of the inclusion of Parliament in electing commissioners.

This article has argued that the current position of Komnas HAM can be explained by looking at the characteristics of human rights reform in Indonesia in general, which has seen the formal recognition of human rights in law, but contestation and a lack of fulfilment in practice. This half-hearted response is intertwined with the manner of reform in Indonesia, in which groups resistant or ambivalent to democracy are accommodated. The accommodation of these resisters, including the military, has inevitably meant that they continue to influence the political agenda. The consequence for both human rights implementation in general and Komnas HAM in particular is that they remain inadequately supported and even actively resisted. 


\section{References}

Aspinall, Edward (2005). Opposing Suharto. Compromise, resistance, and regime change in Indonesia. Stanford: Stanford University Press.

Aspinall, Edward (2010). 'The irony of success', Journal of Democracy 2:20-34.

Azhar, Haris (2014). 'The human rights struggle in Indonesia: International advances, domestic deadlocks', International Journal on Human Rights 11:227-34.

Bourchier, David and Vedi Hadiz (2003). Indonesian politics and society: A reader. New York: Routledge.

Cardenas, Sonia (2014). Chains of justice. The global rise of state institutions for human rights. Philadelphia: University of Pennsylvania Press.

Centre for Human Rights (1995). National Human Rights Institutions. A handbook on the establishment and strengthening of national institutions for the promotion and protection of human rights. New York/Geneva: United Nations.

Crouch, Melissa (2009). 'Indonesia, militant Islam and Ahmadiyah: Origins and implications'. University of Melbourne. [ARC Federation Fellowship 'Islam, Shariah and Governance' Background Paper Series 4.]

Crouch, Melissa (2013). 'Asian legal transplants and rule of law reform: National human rights commissions in Myanmar and Indonesia', Hague Journal on the Rule of Law 5:146-77.

Eldridge, Philip (2002). 'Human rights in post-Suharto Indonesia', The Brown Journal of World Affairs 1:127-39.

Faundez, Julio (ed.) (1997). Good government and law. Legal and institutional reform in developing countries. Houndmills: MacMillan Press.

Hadiprayitno, Irene Istiningsih (2010). 'Defensive enforcement: Human rights in Indonesia', Human Rights Review 11:373-99.

Herbert, Jeff (2008). 'The legal framework of human rights in Indonesia', in: Tim Lindsey (ed.), Indonesia. Law and Society, pp. 456-82. Annandale: The Federation Press.

ICHRP [International Council for Human Rights and Policy] (2004). Performance \& legitimacy: National Human Rights Institutions. Versoix: IC HR P.

Indrayana, Denny (2007). Amandemen UUD 1945. Antara mitos dan pembongkaran. Bandung: Mizan.

Jetschke, Anja (1999). 'Linking the unlinkable? International norms and nationalism in Indonesia and the Philippines', in: Thomas Risse, Stephen C. Ropp and Kathryn Sikkink (eds), The power of human rights. International norms and domestic change, pp. 134-71. Cambridge: Cambridge University Press.

Kansil, C.S.T. (ed.) (2003). Sekitar hak asasi manusia dewasa ini. Jakarta: Djambatan. Kjaerum, Morten (2001). 'Preface', in: Birgit Lindsnaes, Lone Lindholt and Kirstine Yigen (eds), National Human Rights Institutions. Articles and working papers. Copenhagen: The Danish Centre for Human Rights. 
Komnas HAM (1995). Laporan tahunan 1995. Jakarta: Komnas HAM.

Komnas HAM (1996). Laporan tahunan 1996. Jakarta: Komnas HAM.

Komnas HAM (2006). Laporan tahunan 2005. Jakarta: Komnas HAM.

Komnas HAM (2008). Laporan tahunan 2007. Jakarta: Komnas HAM.

Lay, Cornelis, Pratikno, Amalinda Savarani, Derajad S. Widhyharto, Hasrul Hanif, Masa Sukmajati, Miftah Adhi Ikhsanto, Nanang Indra Kurniawan (2002). Komnas HAM 1998-2001. Pergulatan dalam transisi politik. Yogyakarta: Fisipol UGM.

Lindsey, Tim (2008). 'Constitutional reform in Indonesia: Muddling towards democracy', in: Tim Lindsey (ed.), Indonesia. Law and Society, pp. 23-47. Annandale: The Federation Press.

Lindsnaes, Birgit and Lone Lindholt (2001). 'National Human Rights Institutions: Standard-setting and achievements', in: Birgit Lindsnaes, Lone Lindholt and Kirstine Yigen (eds), National Human Rights Institutions. Articles and working papers, pp. 1-48. Copenhagen: The Danish Centre for Human Rights.

Lopa, Baharuddin (1997). 'Lebih Baik Salah, Daripada Tidak Pernah Bersikap', in: Sri Moerni Ali Said (ed), Ali Said di antara sahabat, pp. 225-229. Jakarta: Pustaka Sinar Harapan.

Mertus, Julie A. (2009). Human rights matters. Local politics and National Human Rights Institutions. Stanford: Stanford University Press.

Mertus, Julie A. (2012). 'Evaluating National Human Rights Institutions', in: Ryan Goodman and Thomas Pegram (eds), Human rights, state compliance, and social change. Assessing National Human Rights Institutions, pp. 74-90. Cambridge: Cambridge University Press.

Peters, B. Guy (2013). 'Politicisation: What is it and why should we care?', in: Christine Neuhold, Sophie Vanhoonacker and Luc Verhey (eds), Civil servants and politics: A delicate balance, pp. 12-24. Basingstoke: Palgrave Macmillan.

Pompe, Sebastiaan (1994). 'Human rights in Indonesia. Between universal and national, between state and society', Leiden Journal of International Law 2:85-98.

Pompe, Sebastiaan (2005). The Indonesian Supreme Court. A study of institutional collapse. Ithaca: Cornell Southeast Asia Program.

Pratikno, Cornelis Lay, Amalinda Savirani, Derajad S. Widhyharto, Hasrul Hanif, Mada Sukmajati, Miftah Adhi Ikhsanto and Nanang Indra Kurniawan (2002). Komnas HAM 1993-1997. Pergulatan dalam otoritarianisme. Yogyakarta: Fisipol UGM.

Roosa, John (2006). Pretext for mass murder. The September 3 oth Movement \& Suharto's coup d'etat in Indonesia. Madison: The University of Wisconsin Press.

Sen, Krishna (1996). 'Human what?', Inside Indonesia 46:5-8.

Setiawan, K.M.P. (2013). Promoting human rights. National Human Rights Commissions in Indonesia and Malaysia. Leiden: Leiden University Press.

Smith, Anne (2006). 'The unique position of National Human Rights Institutions: A mixed blessing?', Human Rights Quarterly 28:904-46. 
Smith, Jessica M. Ramsden (1998). 'Komnas HAM and the politics of human rights in Indonesia'. [MA thesis, Canberra, the Australian National University.]

Vickers, Adrian (2005). A history of modern Indonesia. Cambridge: Cambridge University Press.

Wiratraman, Herlambang P.(2014). Press freedom, law and violence in Indonesia: A sociolegal study. Leiden: Leiden University Press. 